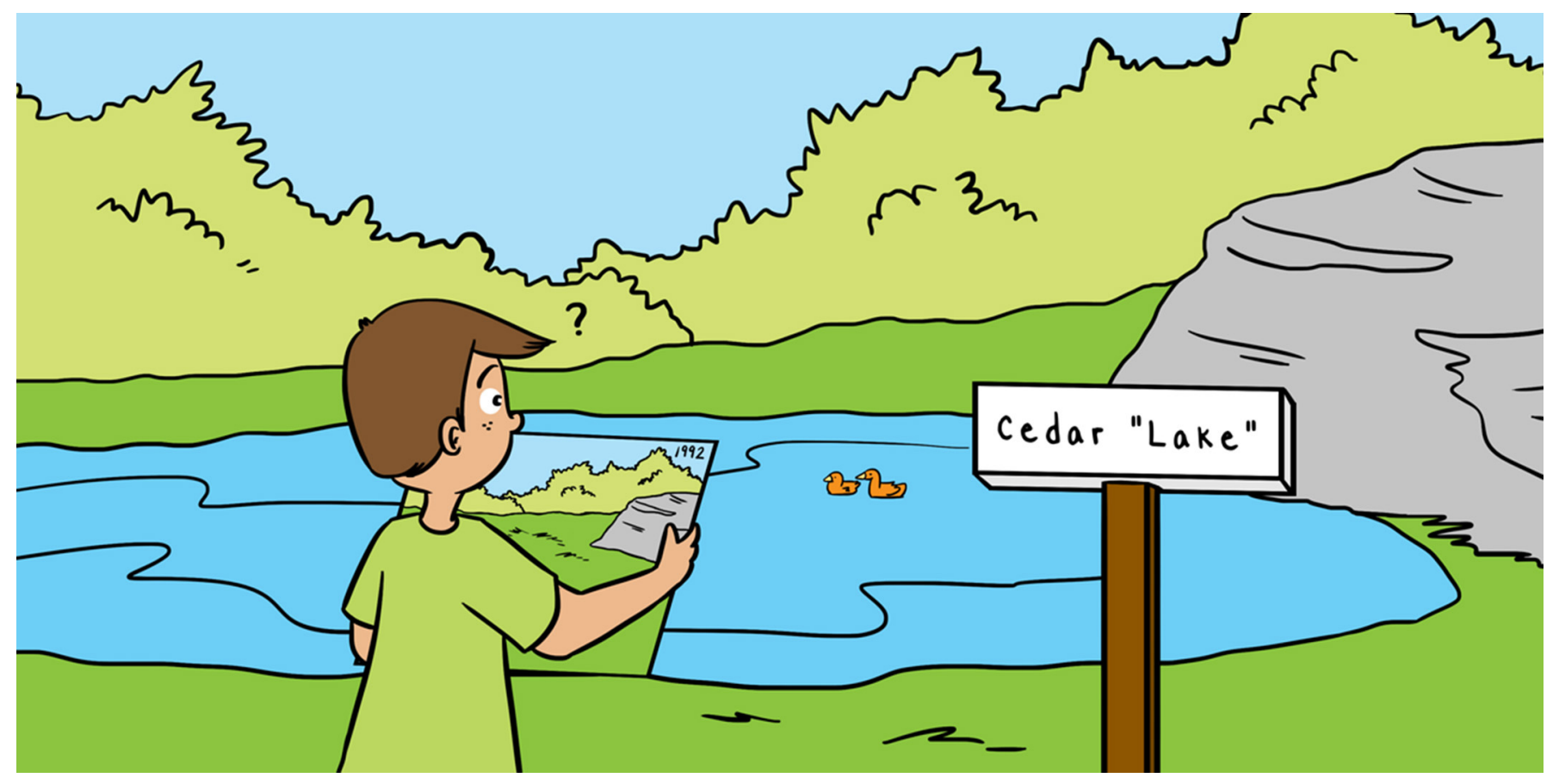

\title{
UNDERSTANDING DIFFERENCES BETWEEN LAKES AND RESERVOIRS
}

\section{Penny Beames ${ }^{1}$ and Stephanie Renee Januchowski-Hartley ${ }^{2 *}$ \\ ${ }^{1}$ Department of Geography, McGill University, Montreal, QC, Canada \\ ${ }^{2}$ Department of Biosciences, Swansea University, Swansea, United Kingdom}

YOUNG REVIEWERS:

AGES: $14-17$
There are many examples of how human activities alter species' habitats, including the damming of lakes or rivers to create reservoirs. We build dams to create reservoirs that provide water and generate electricity for human needs. Scientists have learned that building new dams and creating reservoirs on lakes and rivers changes the local habitat, making it unsuitable for many species that once lived there. Through processes known as environmental flows, reservoirs can be operated to resemble natural lakes. However, we have not kept good records of where we built reservoirs, so scientists have devised creative ways to map where these and associated dams occur across the globe. When we know where reservoirs and dams occur, we are better prepared to determine how these have altered surface water on the planet and impacted animals, plants, and humans. 


\section{LAKE}

An area filled with water, localized in a basin that is surrounded by land

\section{ECOSYSTEM}

A community of interacting organisms and their physical environment.

\section{RESERVOIR}

An enlarged body of water created using a dam or lock.

\section{DAM}

A structure built across a river or lake outlet to hold back water and raise its level.

\section{HYDROELECTRICITY}

Power derived from the energy of falling or fast-running water.

\section{WHAT IS THE DIFFERENCE BETWEEN A LAKE AND A RESERVOIR?}

Lakes come in different shapes, sizes, and depths, and are formed in several ways. Tectonic lakes form where the Earth's crust folds or curves, creating natural basins that can fill with rain or river water. Lake Tanganyika, in Africa, was formed in this way. Lakes can also form when wind, water, or glaciers erode the Earth's crust. The Great Lakes in North America were formed by glaciers that carved out pits as they moved slowly over thousands of years. When the glaciers melted 10,000 years ago, the water filled the pits, which formed lakes. Lakes are often connected to rivers that flow in and out of them, facilitating movement of water, nutrients, and species through ecosystems. Water levels in lakes tend to change slowly and follow seasonal patterns. When snow melts in the spring, or when monsoons occur in the rainy season, the lakes fill up. When the snow has melted and rain subsides, rivers shrink and water levels in the lakes slowly go back down.

Reservoirs, on the other hand, form behind dams created by humans, and range in size from ponds of water that sit outside a city to larger waterbodies that fill entire canyons behind the dams. Unlike lakes, which form by natural processes, reservoirs are created by humans to provide water and hydroelectricity for our own needs [1]. Humans have been building small reservoirs for thousands of years; some reservoirs in Sri Lanka have existed since the year 300! Larger reservoirs associated with dams constructed for water supply or hydroelectricity are created by damming either rivers or lakes. A reservoir is considered large if it contains more than 3 million cubic meters of water, roughly the same as 1,200 Olympic-sized swimming pools [1]. In the last 100 years, we have built larger reservoirs on bigger rivers and lakes, such as the Nalubaale and Kiira hydroelectric dams that control the water levels of Lake Victoria in Africa-the world's largest tropical lake (Figure 1).

Though we build reservoirs of different sizes and for different purposes, these human-made waterbodies share two things in common. First, humans take water from those reservoirs when we need it, which means their water levels change in ways that are very different from naturally occurring lakes. Second, dams that create reservoirs can prevent or limit species movements, both in the upstream and downstream directions, because of their size and the way they alter the flow of water.

We have built so many big dams that now only one-third of the world's longest rivers flow freely, while the rest have at least one dam on them [2]. Some regions of the world, like Texas in USA, have almost no natural lakes, but the rivers there have been dammed to create thousands of reservoirs [3]. These changes influence the species that can live in these ecosystems. 
Figure 1

Lake Victoria is the principal source of the longest branch of the Nile River. It is rich in species and supports millions of people in Uganda, Kenya, and Tanzania. The lake's water levels are maintained by the Nalubaale and Kiira hydroelectric dams, which sit at the lake's outlet, or the beginning of the Nile River.

\section{Figure 2}

Plant, insect, and animal species change when a lake $(A)$ is converted into a reservoir (B) by building a dam. The rapid changes in water levels caused by the dam influence the species that can live there. The dam can also prevent species, particularly fish, from traveling through the ecosystem.

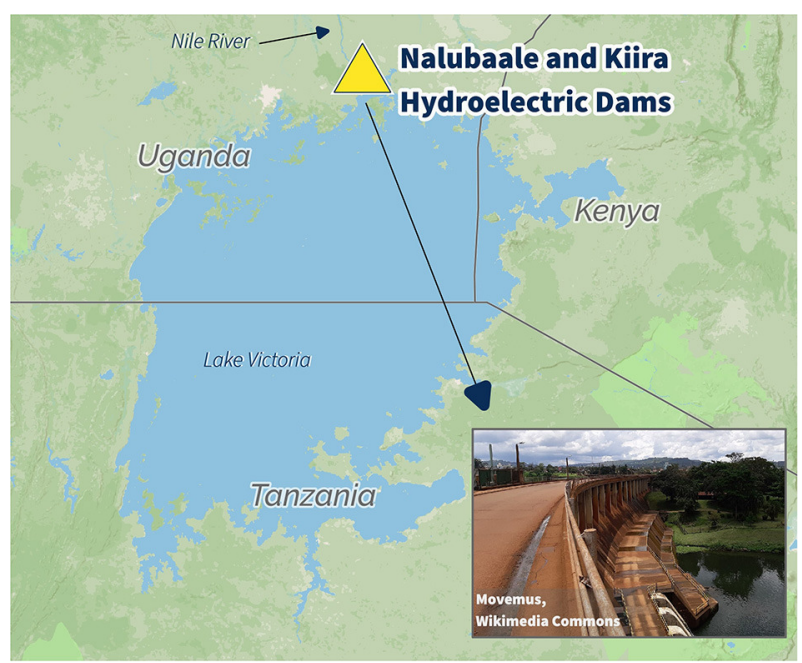

Figure 1

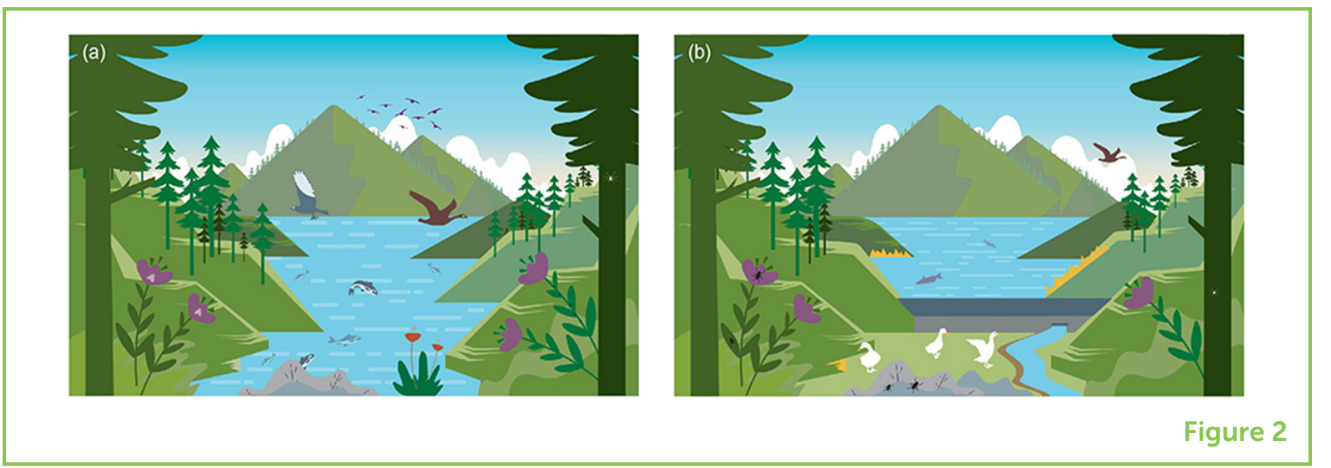

\section{SPECIES TELL US THAT RESERVOIRS ARE NOT LAKES}

While reservoirs might look like and sometimes start from lakes, the species that live in reservoirs are different from the species that lived in the lake or river before it was dammed (Figure 2). Species, such as fishes, plants, and birds that live in lakes have adapted to normal seasonal water level changes. Species adapted to live in lakes and rivers cannot quickly adapt to living in reservoirs, because reservoir water levels change rapidly to meet human needs, rather than adjusting more slowly with the seasons. When we dam rivers, reservoirs can fill with water within 5-10 years, drowning out the river and the surrounding landscape.

Let us look at how fishes might respond to changes caused by a dam and a reservoir. Fishes can be important indicators of change because, unlike birds or reptiles, they cannot leave the water to avoid any changes that occur within it. Because of this, fish can die or be displaced when lakes and rivers are converted to reservoirs, and these species can be replaced by others that are better suited to the new conditions. For example, to have safe places to lay their eggs, many fish species require specific types of rocks, sand, and water flow that only occur in certain parts of a river or lake. Many fish species travel 
ENVIRONMENTAL FLOWS

Quantity, timing, and quality of water flows to sustain both aquatic ecosystems and human needs.

1 PEW, Dam Removal in Washington State Promises to Benefit Fish, Whales, and People, https://pew. org/2AmPQ8m.

2 Global River Obstruction Database, https://scistarter.org/ global-river-obstruction -database-grod.

3 Adaptive Management of Barriers in European Rivers, AMBER, https://amber. international/. through the water between various parts of the lake or river to eat and breed, activities that are critical for their survival. When we create dams and reservoirs though, many fish can lose access to the best spots to lay their eggs or find their favorite foods.

\section{HOW CAN WE REDUCE CHANGES MADE BY DAMS AND RESERVOIRS?}

One way to reduce the ecosystem changes made by dams and reservoirs is to stop constructing them, but this is challenged by the national and international politics of construction projects [4]. Another way that scientists and communities are working to overcome changes in water levels is to operate dams and reservoirs so that they more closely resemble the timing and levels of a natural lake, through processes known as environmental flows [5]. This can mean changing the focus of dam and reservoir management. Instead of focusing only providing water and energy for humans, environmental flows help to ensure that water releases and levels also support the species that once lived in that ecosystem. River pathways, like highway bypasses that avoid city centers, can be constructed around dams to help species, materials, and nutrients move to other parts of the ecosystem. We can also remove older dams and drain reservoirs. In communities where people realize the negative effects of dams on local species, large dams that are beginning to age and might be unsafe are being taken down. ${ }^{1}$

While we have some good ideas about how to reduce the effects of large dams and reservoirs on our lake and river ecosystems, there is one big problem. Governments and individuals have not kept good records of where we have dammed rivers or lakes to make reservoirs. We built a lot of reservoirs before we realized that these changes would impact the plants and animals that we share the planet with. Scientists and other researchers are now tracking down all the reservoirs on the planet. Some scientists and community members, such as those who built the Global River Obstruction Database (GROD), ${ }^{2}$ use satellite imagery available through Google Earth Engine to identify dams on the Earth's rivers. Other scientists, like those who built the AMBER Database, ${ }^{3}$ work with community members to geotag dams and reservoirs through an app on their smartphones (Figure 3).

When we know where the reservoirs are, then governments, researchers, dam owners, and the people who depend on reservoirs can work together to determine how to operate dams and reservoirs in ways that minimize effects on species and the movement of nutrients and materials, and to find places where we can turn reservoirs back into natural lakes and rivers. When a reservoir is no longer needed and the dam is removed, evidence shows that ecosystems can recover, and species begin to return to rivers [6]. As species return, so do 
Figure 3

A community member taking a photo and geotagging a dam and reservoir with the Adaptive Management of Barriers in European Rivers (AMBER) smartphone app (Image courtesy of AMBER Project).

4 EOS, Europe's Rivers Are the Most Obstructed on Earth, https://eos.org/ articles/europes-rivers -are-the-mostobstructed-on-eart.

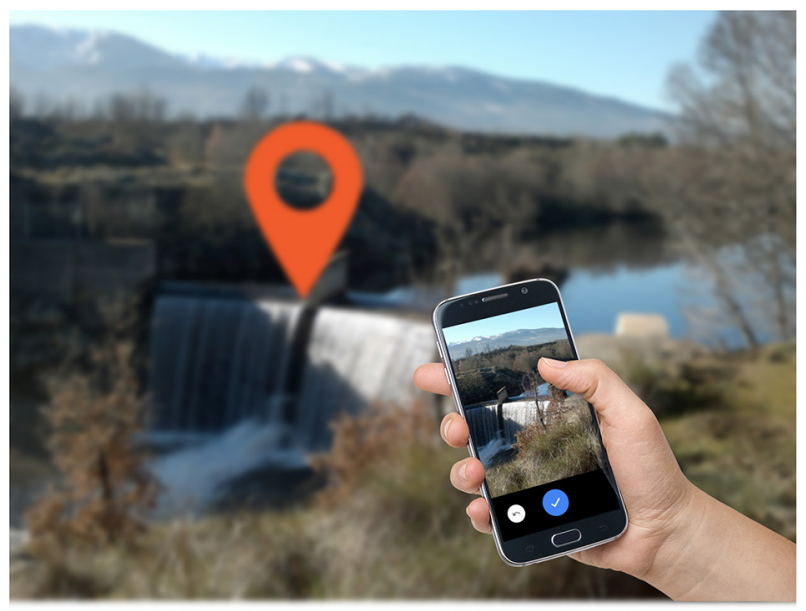

Figure 3

local cultural events and ceremonies that depend on and celebrate them. ${ }^{1}$

\section{CONCLUSION}

Humans have built reservoirs of different shapes and sizes to provide water and hydroelectricity for our needs. However, by turning lakes and rivers into reservoirs, we alter the natural ecosystems and the species that can live within these waterbodies. While we have ideas about how to reduce the effects of large dams and reservoirs on our lake and river ecosystems, we first need to know where these occur across our planet. Scientists are working to find and map the locations of dams and reservoirs, and to find places where we can turn reservoirs back into natural lakes and rivers. One way that communities and schools can get involved is to participate in this global mapping project. For example, the AMBER app can be downloaded and used by people everywhere to map the locations and attributes of dams. ${ }^{3}$ The GROD project has completed its initial tasks, but future opportunities may still be available for young people who want to get involved with mapping dams and reservoirs. ${ }^{4}$ There is space for young people to be creative and develop new methods or to contribute to existing projects, helping to document where dams, reservoirs, and other related infrastructure occur. In this way, everyone can participate helping to conserve natural lake and river ecosystems.

\section{AUTHOR CONTRIBUTIONS}

SJ-H and PB wrote the manuscript and revised it together. PB made the graphics. 


\section{ACKNOWLEDGMENTS}

SJ-H acknowledges funding from the Welsh European Funding Office and European Regional Development Fund Project Number 80761-SU-140 (West). We would like to thank the reviewers who helped to improve the quality of this manuscript. We also thank Bernhard Lehner and the Global Dam Watch Working Group for connecting us and facilitating dialogue about dams, reservoirs, and freshwater ecosystems.

\section{REFERENCES}

1. World Commission on Dams. 2000. Dams and Development: A New Framework for Decision-Making. London, UK:Earthscan.

2. Grill, G., Lehner, B., Thieme, M., Geenen, B., Tickner, D., Antonelli, F., et al. 2019. Mapping the world's free-flowing rivers. Nature 569:215-21. doi: 10.1038/ s41586-019-1111-9

3. World Atlas. How Many Natural Lakes Are In Texas? Available online at: https://www.worldatlas.com/articles/how-many-naturallakes-are-in-texas.html (accessed June 12, 2020).

4. Ansar, A., Flyvbjerg, B., Budzier, A., and Lunn, D. 2014. Should we build more large dams? The actual costs of hydropower megaproject development. Energy Policy 69:43-56. doi: 10.1016/j.enpol.2013.10.069

5. Richter, B. D., and Thomas, G. A. 2007. Restoring environmental flows by modifying dam operations. Ecol. Soc. 12:1-26. doi: 10.5751/ES-02014-120112

6. Rubin, S. P., Miller, I. M., Foley, M. M., Berry, H. D., Duda, J. J., Hudson, B., et al. 2017. Increased sediment load during a large-scale dam removal changes nearshore subtidal communities. PLOS ONE 12:e0187742. doi: 10.1371/ journal.pone.0187742

SUBMITTED: 21 November 2019; ACCEPTED: 11 December 2020; PUBLISHED ONLINE: 22 January 2021.

EDITED BY: Anna Regoutz, University College London, United Kingdom

CITATION: Beames P and Januchowski-Hartley SR (2021) Understanding Differences Between Lakes and Reservoirs. Front. Young Minds 8:513858. doi: 10. 3389/frym.2020.513858

CONFLICT OF INTEREST: The authors declare that the research was conducted in the absence of any commercial or financial relationships that could be construed as a potential conflict of interest.

COPYRIGHT (c) 2021 Beames and Januchowski-Hartley. This is an open-access article distributed under the terms of the Creative Commons Attribution License (CC BY). The use, distribution or reproduction in other forums is permitted, provided the original author(s) and the copyright owner(s) are credited and that the original publication in this journal is cited, in accordance with accepted academic practice. No use, distribution or reproduction is permitted which does not comply with these terms. 


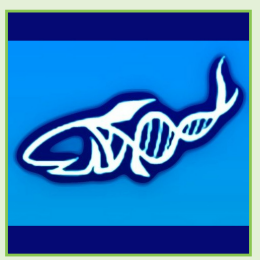

\section{YOUNG REVIEWERS}

\section{FDR-HB_PERU IGEM TEAM, AGES: 14-17}

We are a synthetic biology team with the international Genetically Engineered Machine (iGEM) in Lima, Peru. We are the only high school team in Latin America and are proud of our work with creating a detector for cadmium using bacteria. Most of us are second language learners and the age range of our group is 14-17 years old. We love GMOs!

\section{AUTHORS}

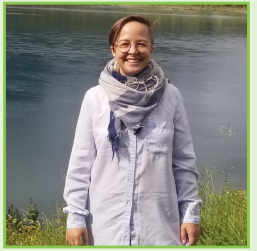

\section{PENNY BEAMES}

Penny grew up on a lake and has since lived within walking distance of another lake, two straits, and six rivers. She began to study rivers after white water rafting on the Ganges in India and has been working to protect them ever since. She began her research studying how countries share rivers that cross borders. Penny is now a Ph.D. researcher at McGill University in the Geography department where she studies how dams and other river barriers affect people and ecosystems.

\section{STEPHANIE RENEE JANUCHOWSKI-HARTLEY}

Stephanie grew up between lakes and rivers that form the Laurentian Great Lakes Basin. As a young person, she formed a love for marsupials, particularly koalas, and for her doctoral degree moved from the shores of Lake Michigan to tropical Australia where she focused on questions about the conservation of rivers. She is happiest outdoors, spending time in water, swimming, and exploring for different creatures. It is her hope to inspire others to connect with their local fresh or salty waters and the species that live below the surface. *s.r.januchowski@swansea.ac.uk 